\title{
Unintentional Reverse Transfer from L2 (English) to L1 (Spanish) in Tertiary Levels
}

\author{
GLORIA LUQUE AGULLÓ* \\ University of Jaén (Spain)
}

Received: 16/12/2019. Accepted: 05/11/2020.

\begin{abstract}
This study attempts to reveal whether there is unintentional reverse transfer L2 $\rightarrow$ L1 (English-Spanish) in the oral L1 production of university learners in formal contexts. The languages used by learners influence each other, and this transfer may occur from the first to the second language (direct transfer), or from the second to the first (reverse transfer), the focus of this work. Thus, an exploratory study was implemented with two groups of participants with different L2 proficiency levels. They had to retell, using their L1, a soundless video. Their production was recorded, transcribed and examined. Consistent with other studies, results suggest unintentional reverse transfer occurs more frequently when there is a lower level of L2 competence, or, alternatively, its effects have a more evident negative outcome for these learners. Pedagogically speaking, being able to identify successful reverse transfer strategies with a positive outcome may have important implications for bilingual educational contexts.
\end{abstract}

KEYWORDS: L1; L2; Direct transfer; Reverse transfer; Video retelling; Tertiary education; Bilingual education.

\section{INTRODUCTION}

The number of speakers of more than one language has increased exponentially in the last decades, and, following Hinkel (2011:12), "[this] trend toward globalization sparks interest for bilingual abilities". In an increasingly more globalized world, and with the intensification

\footnotetext{
*Address for correspondence: Departamento de Filología Inglesa, Campus Las Lagunillas, Edificio Humanidades y CC Educación (I), University of Jaén, Spain; e-mail: gluque@ujaen.es
} 
of migratory movements, learning and using more than one language is an essential competence for social and promotion issues. In this context, there has been a rise of what Cook calls "multicompetent speakers" (2003:2), who have "knowledge of two or more languages in one mind". In Europe, the proliferation of language learners and multicompetent users stands parallel to the creation of the Common European Framework of Reference (CEFR) (Council of Europe, 2001; 2018), which has established global achievement levels (A1, A2, B1, B2, C1, C2) for many languages all through Europe.

Following the establishment of these levels, diverse European educational policies and projects have promoted the achievement of a specific level (for instance, B1 or B2 in different Spanish regions) as a requirement for completing a university degree. Another fundamental European educational policy has been the development of bilingual education by means of CLIL (Content and Language Integrated Learning) (Lasagabaster and Doiz, 2016; Mehisto, \& Genesee, 2015), or, more recently, EMI (English as a Means of Instruction) (Dearden, 2015). Both methodologies have a dual focus: the acquisition of contents and language. However, whereas CLIL is addressed to primary and secondary levels, and has an explicit focus on acquiring the second language and culture, EMI is addressed to tertiary levels, and although the language of instruction is English, there is no explicit focus on language learning.

The requirement of achieving a certain CEFR level before finishing a University degree, together with the implementation of bilingual methodologies in every educational level has led to a remarkable increase of multicompetent speakers who have learnt the target language in formal contexts, a situation remarkably widespread throughout Europe, including the setting of this study, Spain. This has motivated a proliferation of research about L2 learning and teaching related to how, when and why the L2 competence is achieved (Norris \& Ortega, 2012) and what factors influence the process (Larsen-Freeman \& Long, 2014).

This research about L2 learning, still continuing, originated by the middle of the last century, when the notion of transfer was developed. This notion attempted to establish the linguistic behaviour and proficiency of L2 language learners by cataloguing the differences and similarities in the languages being learned and used. Namely, the origins of the SLA discipline focused on the influence of the mother tongue (L1) on the second or foreign language (L2), that is to say, $\mathrm{L} 1 \rightarrow \mathrm{L} 2$. This phenomenon, termed transfer for the first time by Weinreich (1953:1) was defined as "those instances of deviation from the norms of either language which occur in the speech of bilinguals as a result of their familiarity with more than one language". The study of transfer developed by way of the so called Contrastive Analysis (CA) (Stockwell et al., 1965), which designed Hierarchies of Difficulty systematically comparing elements in the two languages in order to establish the difficulty of learning L2 elements as compared to equivalent items in the L1. When the two terms were 
similar, positive transfer would follow, whereas when different, negative transfer would occur. In this fashion, negative transfer or interference should be predicted and then avoided by the use of specific teaching techniques. A decade later, the notion of interlanguage arose as the study of the learners' language (Selinker, 1972; Selinker \& Rutherford, 2013). This move away from a behavioural perspective rejected CA and started documenting all types of errors, those due to negative transfer and other errors produced by overgeneralization of L2 rules, communication demands or simplification processes, among other causes. The notion of Interlanguage focused on learners' errors and production phenomena, but it also achieved to develop an alternative framework to systematically research the language produced by adult second-language learners. In Tarone's words (2018:748), "to objectively identify psycholinguistic processes (transfer included) that shape learner language, explaining how learners set up interlingual identifications across linguistic systems".

In the $80 \mathrm{~s}$, transfer phenomena were also contemplated not only considering the formal/linguistic correspondences between languages, but related to learners' perceptions. Kellerman (1986) introduced the term "transferability", which explained how transfer depends on learners' intuitions about the similarities and differences they perceive about the two languages. After that, Odlin (2006) refined this idea of perceived transferability, indicating that transfer may be conscious or not, and may have a negative or positive outcome in the L2. In fact, according to these authors (Kellerman, 1986; Odlin, 2006: 23-4), perceived transfer may affect learning and production more than the actual similarities between languages.

To conclude, the notion of (negative) transfer from the L1 to the L2 has formed part of the SLA literature for half a century, assuming that there is some sort of cross linguistic influence (CLI) due to a lack of competence in the L2. Following this perspective, the learner must compensate for that deficiency, so a wide range of SLA research has focused on the notion of fossilization, including transfer errors, use of compensatory strategies, or language switch phenomena (Tarone, 2006). In the case of bilingual contexts, the attention has been on the study of attrition in heritage language speakers (Chamorro, Sorace, \& Sturt, 2016). All these phenomena arising from a negative view of the role the L1 has on the L2.

Other disciplines have followed a similar error focused approach, such as psychology, assuming that the use of more than one language produces a competition effect (Bates \& MacWhinney, 1989) which disrupts the languages of these (aspiring) bilinguals. In short, contact phenomena produced by the learning or use of more than one language have been considered as negative transfer or interference, and attributed to learners' cognitive deficiencies or lack of competence. More recently, this view, in which the proficiency of language users/learners is compared to that of monolingual speakers (see monolingual bias, in Cook, 2003; Ortega, 2009), has been rejected, establishing the more encompassing term of multicompetent speakers (Cook, 2009), who have plurilingual awareness of the languages 
they use (Pavlenko, 2016). When more than one language is employed by a speaker or a community, cross-linguistic influence (Ringbom \& Jarvis, 2008: 112) may take place. This more neutral perspective has moved away from the notion of negative transfer (L1 $\rightarrow$ L2) to explore contact phenomena, considered by Bullock \& Toribio (2009) as those phenomena produced by the simultaneous use of two or more languages independent of direction $(\mathrm{L} 1 \rightarrow \mathrm{L} 2$ or $\mathrm{L} 2 \rightarrow \mathrm{L} 1)$. Nowadays, cross linguistic influence attempts to explain how leaners rely on their notions about the formal similarities of individual elements and functional equivalences between both systems. The global transfer of a multicompetent speaker or learner (including receptive and productive aspects) depends, among other factors, on the similarities this user may perceive between the two languages. Transfer (contemplated in a neutral sense) can be detected in linguistic forms and morphosyntactic structures, but it also extends to the meanings, functions and pragmatic aspects associated to those forms (Cenoz, 2003). In sum,

There has been some change in the way some of the psycholinguistic processes shaping interlanguage are viewed. For example, the study of transfer has been expanded and termed "crosslinguistic influence," exploring how NL, IL, and TL influence one another. We have learned transfer may operate selectively: for example, some things transfer from the NL to IL, and some things do not. A crucial question is: what gets transferred? (Tarone, 2018:5).

Currently, most SLA research dealing with transfer phenomena still explores the influence of the L1 on the L2, but there are very few studies focusing on the influence of the L2 on the L1 (exceptionally, see Cook, 2003). In order to study the unique and distinctive features in the production of users and learners of more than one language, research should focus both on the dual influence of the L1 on the L2 $(\mathrm{L} 1 \rightarrow \mathrm{L} 2)$ and that of the L2 on the L1 (L2 $\rightarrow$ L1), moving away from the monolingual bias in SLA (Cook, 2003; Ortega, 2009) or the competition effect in psychology (Bates \& MacWhinney, 1989). In fact, research in the last decade (Bialystok, Craik \& Luk, 2012) is supporting this alternative view of contact phenomena as the cognitive ability of being able to use both codes simultaneously, not as the consequence of cognitive deficiencies. In sum, having knowledge of more than one language increases cognitive skill training (or brain training), develops the use of metalinguistic abilities and maximizes attention processes.

This comprehensive position has also been adopted within the educational context, which has established a translanguaging perspective (Flores and Aneja, 2017; Turnbull \& Dailey-O'Cain, 2009). This view considers code switching and other contact phenomena as an intrinsic aspect of bilingual production, accomplishing different functions in the linguistic context, and contributing, specifically in the case of learners, to an improvement in the comprehension, learning and use of an L2. In other words, from this stance, both languages would (and should) be used because they are simultaneously available in the speaker's mind. 
Consequently, it is nowadays accepted that the languages of learners unavoidably influence each other, and this transfer may take place from the first to the second language (direct transfer: $\mathrm{L} 1 \rightarrow \mathrm{L} 2$ ), or from the second to the first one (reverse transfer: $\mathrm{L} 2 \rightarrow \mathrm{L} 1$ ), so that the mother tongue of multicompetent speakers shows different features to that of monolinguals (Cook, 2003; 2009). As mentioned above, and following recent research (Flores and Aneja, 2017) this influence may be positive, contrarily to what was believed until recently.

It would be necessary, then, to classify the types of cross linguistic influence observed in the language(s) of a multicompetent speaker or learner, so that we arrive at a non-biased and more comprehensive description of these phenomena. Consequently, the following section provides a taxonomy to categorise transfer.

\section{A DESCRIPTION OF TRANSFER PHENOMENA}

A classification of the types of transfer adapted from the taxonomy provided by Jarvis and Pavlenko (2008:19) is shown in the following Figure (see Figure 1). This classification has omitted those aspects related to the type of knowledge (implicit vs. explicit), intentionality (intentional vs. unintentional) and manifestation (overt vs. covert), included by the aforementioned authors, because of the narrower scope of the present work.

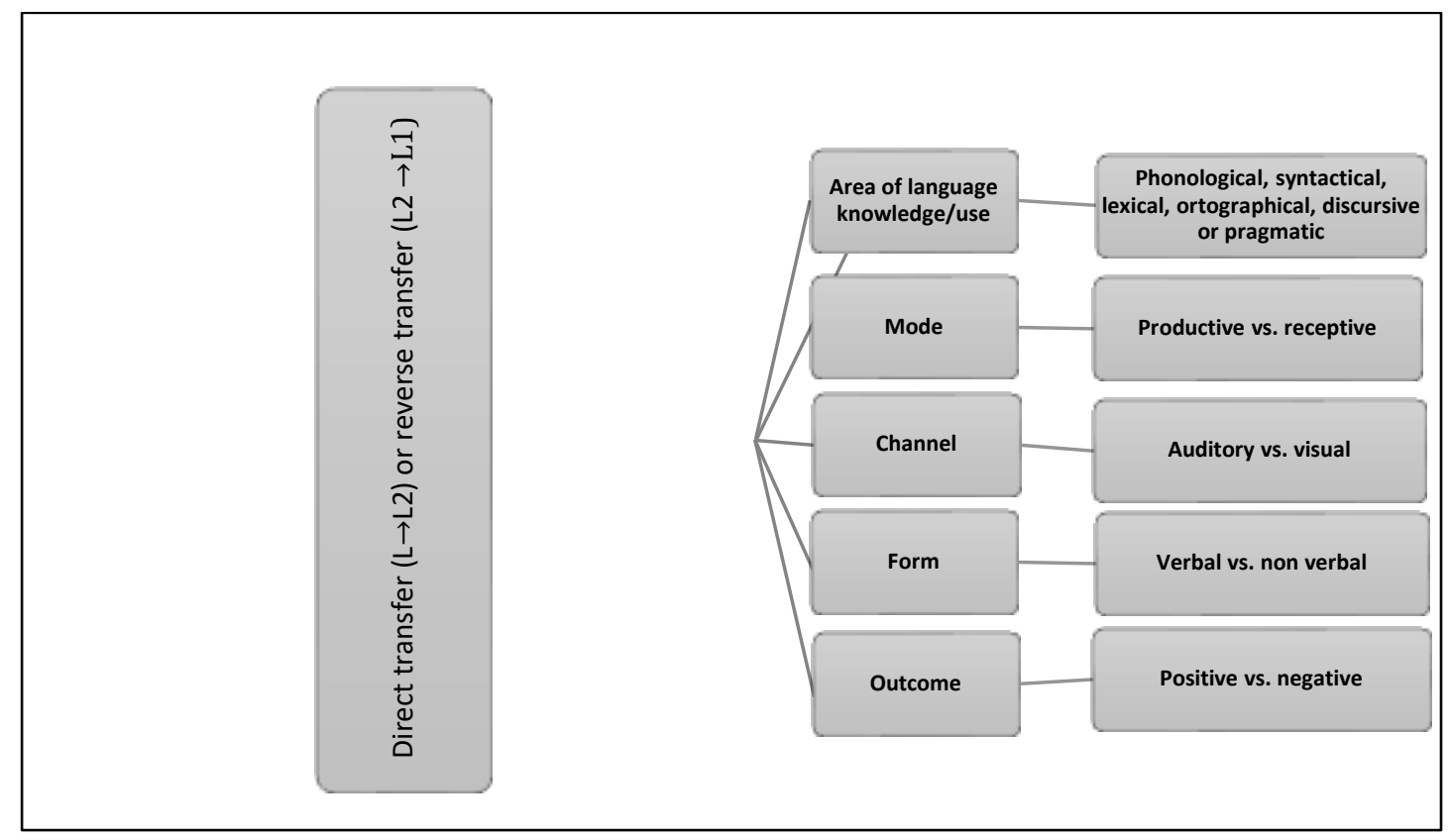

Figure 1. Types of transfer.

Considering this taxonomy as a starting point, all those phenomena related to transfer can be systematically organised and classified following the six categories. Thus, an "error" in the production of a speaker or learner such as pasar un examen (aprobar un examen-pass an exam) may be classified as (a) reverse transfer (L2 $\rightarrow \mathrm{L} 1)$, (b) lexical, as it affects the choice of (C) Servicio de Publicaciones. Universidad de Murcia. All rights reserved. IJES, vol. 20(3), 2020, pp. 57-76 
verb (c) productive, (d) auditory, (e) verbal, and (f) with a negative outcome, leading to what has conventionally been considered an error. Pintura removable (pintura lavable-removable painting) written in the label of a can would also be an example of (a) reverse transfer $(\mathrm{L} 2 \rightarrow \mathrm{L} 1)$, (b) lexical, as it affects the choice of adjective (c) productive, (d) visual, in this case, (e) verbal, and (f) with a negative outcome. Although both instances, but particularly the second one, could be explained in an alternative way (i.e. a bad translation), we will adhere to the point of view provided by Jarvis and Pavlenko's taxonomy (2008).

Besides exploring the types of errors, research has also examined how certain factors may affect the type and degree of cross-linguistic influence (Jarvis \& Pavlenko, 2008) (see Table 1).

Table 1. Factors affecting cross linguistic influence.

\begin{tabular}{|l|l|}
\hline 1 & Linguistic and psycholinguistic aspects \\
\hline 2 & Developmental, cognitive and attention factors \\
\hline 3 & Language competence and experience \\
\hline 4 & Learning environment \\
\hline 5 & Language use \\
\hline
\end{tabular}

Concerning the characteristics of language, the first group of factors include cross linguistic similarity, or how similar the two languages are perceived by the L2 user; the area of language use, including phonology, orthography, lexis, semantics, morphology, sintax, discourse and pragmatics. Frequency, refering to the fact that the most recurrent L1 or L2 forms are more likely to be incorporated in the user's production; recency, in the sense that the most recently used or acquired language tends to be the one most likely transferred, and salience, or how noticeable a form is perceived. Markedness and prototipicality are related to the degree to which a form is special, atypical or language-specific versus a non-marked or prototypical form. Unmarked forms tend to transfer more, particularly if the form is frequent or salient. Finally, this first category includes the linguistic context, although evidence on the influence of linguistic context on reverse transfer is currently anecdotal (Jarvis \& Pavlenko, 2008).

The second group of factors deal with cognitive capacities, resources and development. Degree of attention to form, universal acquisition processes and use of learning strategies are also integrated here.The third category considers prior knowledge and use of languages, namely, learning age, duration, frequency and amount and length of exposure to the language(s), linguistic competence and number and order of acquired languages. The fourth and fifth categories are related to external factors. Whereas the first one includes the learning context, formal or natural, and the teaching approach, with a focus on form(s) or with a focus on communication, the second category refers to aspects related to language use such as idiolect, level of formality, interlocutors, and type of task.

(C) Servicio de Publicaciones. Universidad de Murcia. All rights reserved. IJES, vol. 20(3), 2020, pp. 57-76 
The scope of factors affecting cross linguistic influence is wide and diverse, similarly to the possible types of transfer produced in the discourse of a multilingual speaker or learner. Moreover, globalization issues may explain the increasing number of possible occurrences of this type of phenomena, as there is an expanding number of multicompetent speakers. In fact, both language users and learners show a high probability to establish conscious connections between the languages they use, employing explicit memory processes and monitoring their production. Moreover, and specifically in the case of reverse tranfer, this expected and helpful contact between two or more languages can be observed in certain linguistic patterns used by bi/plurilingual speakers, who may reorganize their inferences, their categorization processes, and even the recall of certain terms of the L1, and all these phenomena are influenced by the L2 (Jarvis \& Pavlenko, 2008).

However, there are very few studies (exceptionally, Cook, 2003; and for three languages, Aronin \& Hufeisen, 2009; Burton, 2013; Cenoz, 2003; De Angelis \& Dewale, 2011; Jessner, Megens \& Graus, 2016; Woll, 2018) which have considered the specific effects of reverse transfer, and most of the evidence has been largely anecdotic or not generalizable following Cook (2003) and Jarvis and Pavlenko (2008). Although reverse transfer has not yet been sufficiently explored, in the last two decades there has been an increase of studies on cross linguistic influence, either independent of direction, or focusing on direct transfer of more than two languages (L1-L2//L2-L3) (i.e. Alonso, 2016). Most of these studies have explored syntactical and lexical aspects. Transfer within the syntactical area has examined prepositions (Alonso, Cadierno \& Jarvis, 2016), articles (Ekiert \& Han, 2016), gender (Athanosopoulos \& Boutonnet, 2016), or subject-verb inversion (Cuza, 2013), among other issues. Within the lexical field, transfer has examined L1-L2 cognates (Burton, 2013; Helms-Park \& Dronjic, 2016), morpho-phonological errors, semantic errors, or both (Jarvis \& Pavlenko, 2008), code switching (Bullock \& Toribio, 2009; Turnbull \& DaileyO'Cain, 2009), and lexical borrowing (Muñoz-Basol \& Salazar, 2016). In fact, when two languages are in contact, there is a degree of cross linguistic influence whose most direct and obvious manifestation is at the lexical level (Muñoz-Basol \& Salazar, 2016), in particular, by lexical borrowing. Although this tends to be the most immediate manifestation, it would be advisable to include not only lexis, but syntax, as "unintentional transfer involving the mother tongue tends to predominantly affect grammar, while unintentional transfer between nonnative languages is generally lexical in nature" (Burton, 2013:1). Thus, it may seem relevant to explore how these two aspects would be affected by reverse transfer.

In sum, given the increase of multilingual speakers and learners, and, connected to this, the progressively closer contact between languages, it is necessary to incorporate the study of reverse transfer $\mathrm{L} 2 \rightarrow \mathrm{L} 1$ in educative contexts, either monolingual or bilingual, to achieve a more comprehensive and non-biased view of how the L1 production of multicompetent users/learners differs from that of monolingual speakers. Thus, this work focuses on the formal educational context, in particular the tertiary setting, as university (c) Servicio de Publicaciones. Universidad de Murcia. All rights reserved. IJES, vol. 20(3), 2020, pp. 57-76 
students should have an advanced linguistic proficiency and metalinguistic ability for their L1, and, in the case of English Philology students and other related language degrees, in their L2. Besides, these students, considered aspiring bilinguals (expected minimum level B2 following the CEFR), tend to receive constant input in both languages, as university lectures and interactions occur in the $\mathrm{L} 2$, but the $\mathrm{L} 1$ is used everywhere else.

Therefore, this work will attempt to determine what are the effects of the L2 (English) on the L1 (Spanish) of advanced learners witnin formal educational contexts. In particular, we will explore whether unintentional reverse transfer affects the L1 production of L2 advanced learners in the tertiary context. Secondly, if transfer does in fact exist, we aim to explore what is the type and frequency of occurrence.

\section{RESEARCH QUESTION}

Is there unintentional reverse transfer L2 $\rightarrow \mathrm{L} 1$ (English-Spanish) in the oral L1 production of university learners?

\section{STUDY}

\subsubsection{Participants}

To control diverse sociodemographic and cognitive aspects, two matched groups enrolled at the University of Jaén (Spain) with the same native language (Spanish), took part in the study. Participants' data was gathered by means of a google questionnaire sent to their personal email after their acceptance to participate in the study (see Appendix). This questionnaire contained three sections which enquired about the participants' general data, learning experience and L2 use. General data requested their sex, age, level of L2 competence and whether they had L2 friends. Learning experience considered the age at which they had started learning the L2, the number of years learning the language, the range of contexts where their L2 learning occured, and the length and type of immersion periods in the L2 or their own country. L2 use enquired about the context(s) where they utilize the L2, what is their use of $\mathrm{L} 2$ receptive skills, and how many hours per week they devote to using the target language. The questionnaire reflects some of the factors considered in Table 1 above, although two of them were excluded. First, linguistic and psycholinguistic aspects were not taken into acount. Even though all the subjects shared the same two languages, the scope of the study did not include a (psycho)linguistic comparison between the L1 and the L2. Second, developmental, cognitive and attention factors, although important, were not examined, again because participants were roughly the same age and had a similar educational level, so they were expected to have a similar cognitive development. Furthermore, these two groups of variables were not crucial to our research at this stage. However, the last three factors were considered relevant following Jarvis and Pavlenko (2008), and consequently, they were included in the survey.

(C) Servicio de Publicaciones. Universidad de Murcia. All rights reserved. IJES, vol. 20(3), 2020, pp. 57-76 
Data from the questionnaire show that the two groups of participants were similar in contextual variables (tertiary context), age, and educational level, discarding extraneous variables. The bilingual group was formed by 15 postgraduate English philology students enrolled in a TEFL master degree, with a minimum entrance requisite of a B2 level following the CEFR descriptors (Council of Europe, 2001). Their average age was 23, and $80 \%$ of the students reported having no L2 native friends. The control group, also formed by 15 students with an average age of 18, had no connection with language degrees, and were required to have very little or no L2 accreditation, although, surprisingly, 44\% reported having L2 friends, as opposed to the $20 \%$ in the bilingual group. As regards their proficiency level, data are shown in Table 2, expressed in terms of percentages. Athough the difference in levels for the two groups is apparent, and our objective was to compare individuals with no L2 competence with multicompetent subjects, nowadays it is practically impossible to find individuals who are complete monolinguals (Cook, 2003). That is also the reason of the difference in average age for the two groups, as before degree completion a B1 level must be certified, whereas enrolling in the master degree requires a minimum B2 level. Before degree completion, then, some individuals may not have developed their L2 proficiency to a significant level, and that made them potential participants.

Table 2. Accredited level of English for bilingual and control groups.

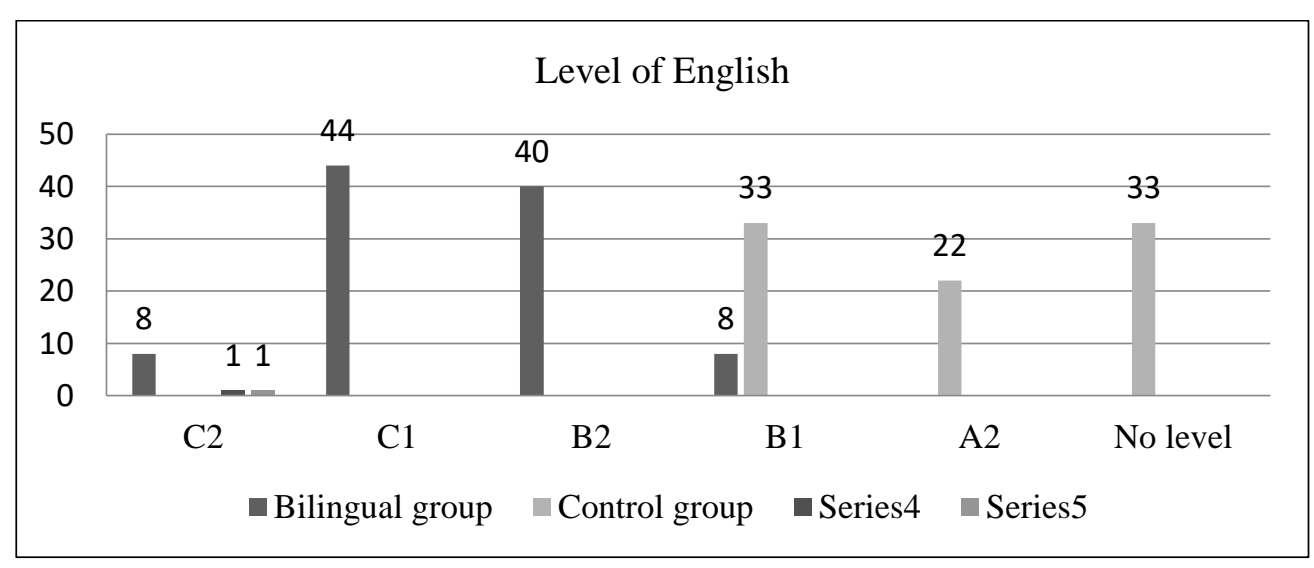

The learning experience of both groups is summarised in Table 3. Most learners in both groups started between the ages of 5 and 8 , and had been learning the L2 for a minimun of 8 years or more. Whereas most of the bilingual students had combined mainstream education (Mainstream ed.//ME) with learning at private academies (Private ac.//PA), or additional stays in the L2 country, the control goup had basically learned through mainstream education, although a third of the participants had also attended a private academy. No one in the control group reported learning visits to the L2 country. As regards the immersion periods, the bilingual group had spent one month or less $(50 \%)$ or between one and three months $(25 \%)$ in an L2 country, staying either with L2 natives or with L1 speakers. $22 \%$ of 
the control group also reported having spent one month or less in immersion, but only with other L1 speakers.

Table 3. Learning experience for bilingual and control group.

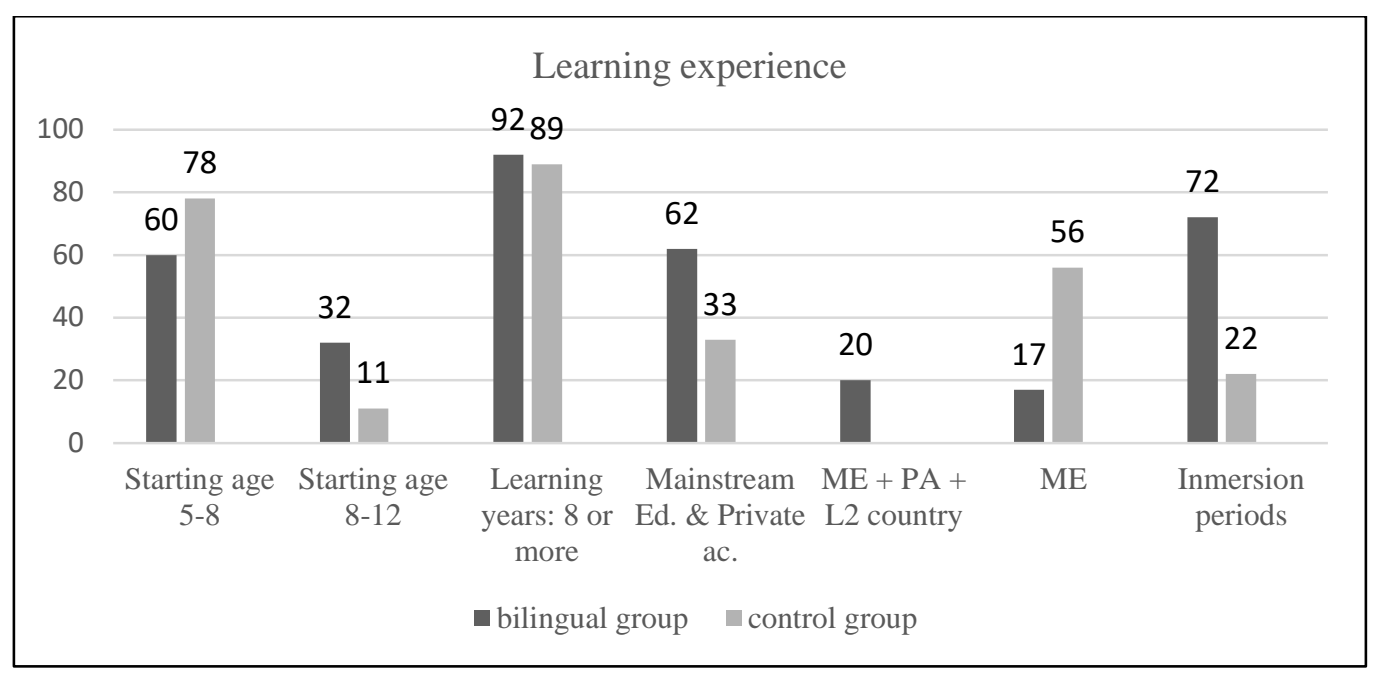

L2 use is shown in the following three Tables (Table 4, 5 and 6), detailing the differences between the contexts, receptive skills and number of hours devoted to the target language for the control and the bilingual groups. Table 4 shows the different contexts where participants used the L2, including their home, friends, university contexts, internet and computer related activities, and several of these situations simultaneously. The bilingual group used the L2 either in two or more contexts or at the university, whereas the control group did not use the target language $(33 \%)$ or used it at the university, for internet related activities, or in several parallel contexts (22\% on each occasion).

Table 4. Contexts where the target language is used.

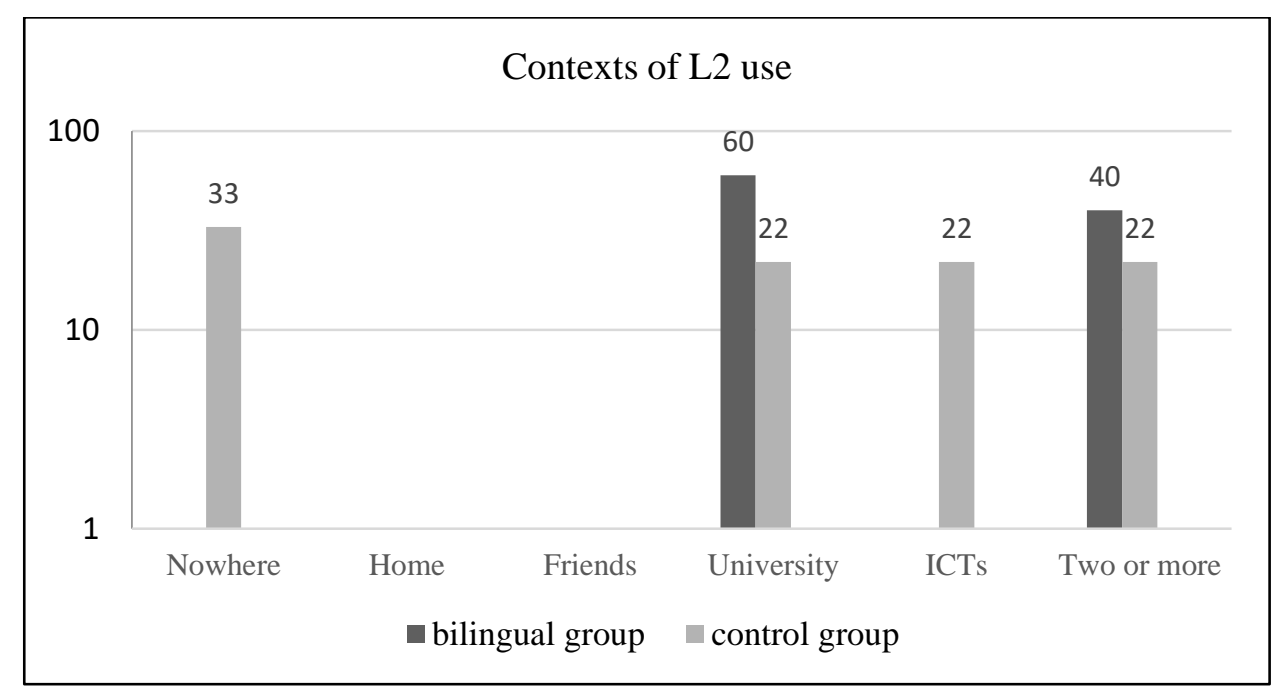

Next, we examined L1 and L2 use of receptive skills (see Table 5). Participants were asked whether they listen and read only in the L2, only in the L1, or they do it using both (C) Servicio de Publicaciones. Universidad de Murcia. All rights reserved. IJES, vol. 20(3), 2020, pp. 57-76 
languages. In general, the bilingual group reported reading and listening in both languages (more than an $80 \%$ ), whereas only a $44 \%$ of the control group reported doing the same. Neither of the groups read only using the target language, and very few people listened only the L2.

Table 5. Receptive skills used in L1 and/or L2.

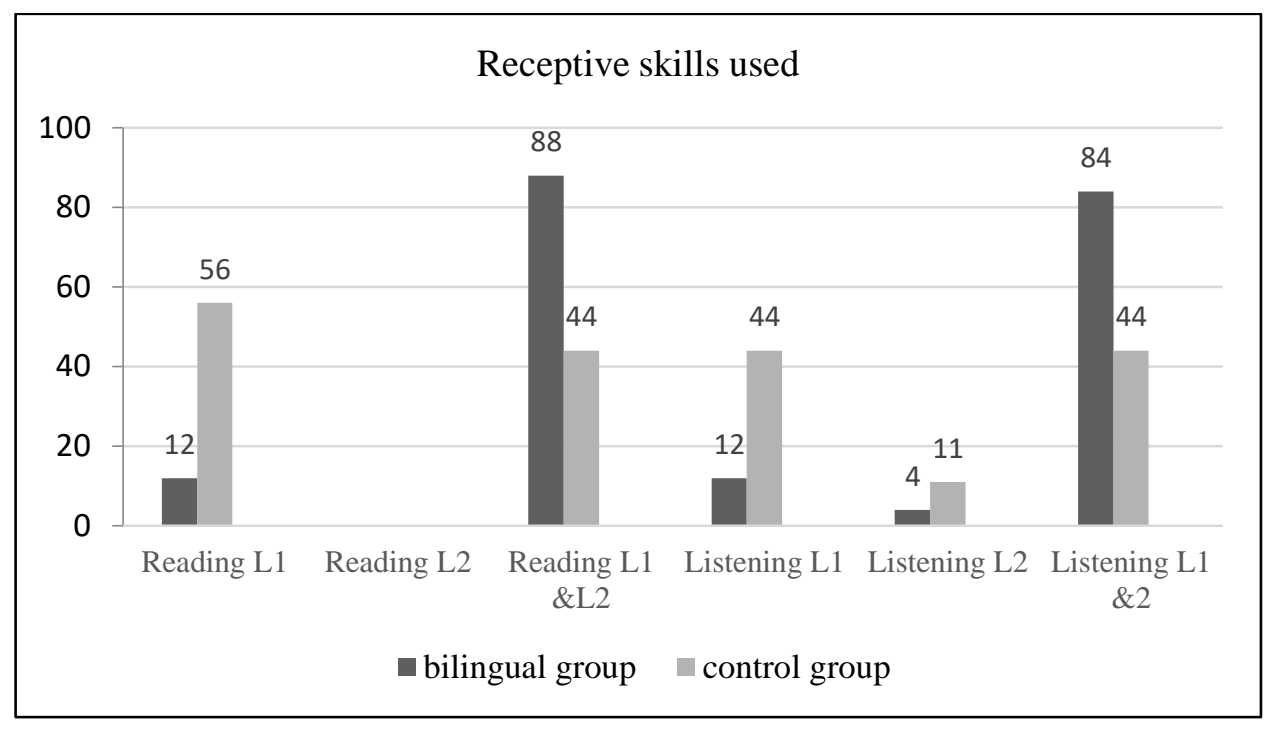

Finally, language use also included conveying the number of hours per week participants estimated they devoted to using the target language. As shown in Table 6, most of the control group did not use the L2 (56\%), or used it between 5 and 10 hours a week, whereas the bilingual group had a more frequent use. Surprisingly, no participant reported using the target language 20 hours per week or more. Maybe this is due to the setting (L1 country), where the target language is not customarily used, thus leading to lack of opportunities for L2 exposure and practice.

Table 6. Hours per week of L2 use.

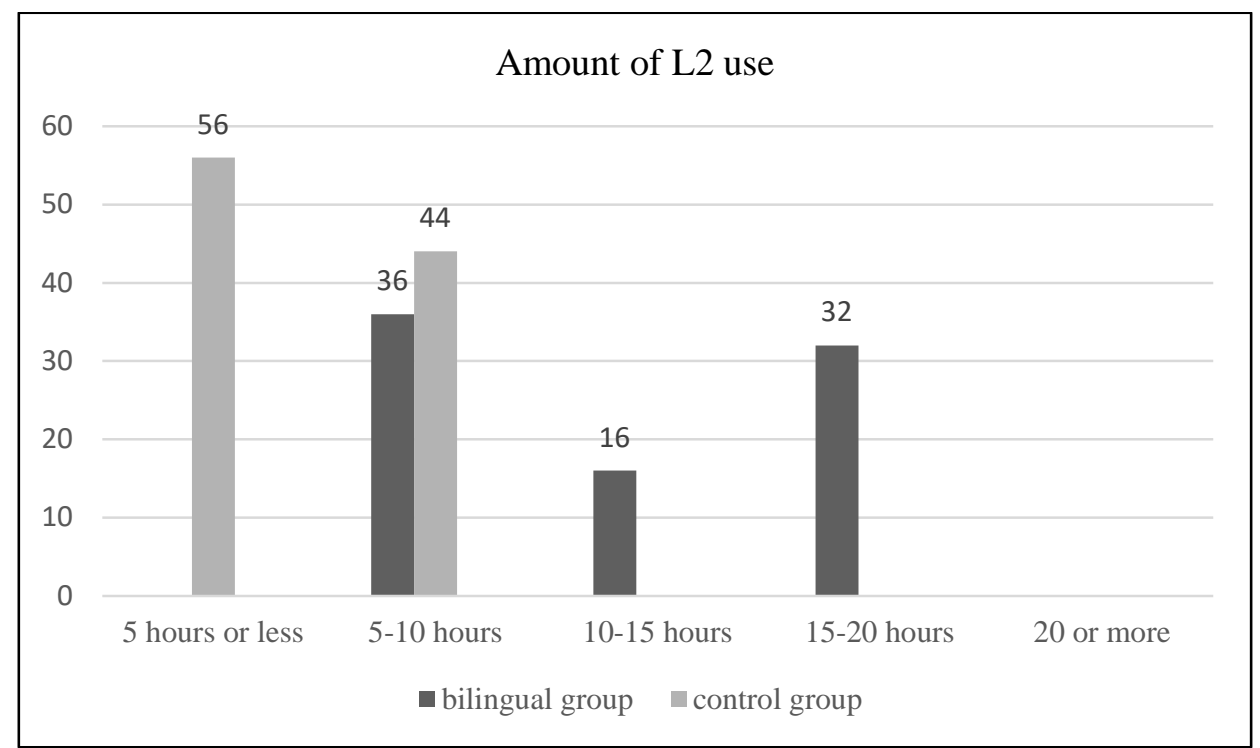

(C) Servicio de Publicaciones. Universidad de Murcia. All rights reserved. IJES, vol. 20(3), 2020, pp. 57-76 Print ISSN: 1578-7044; Online ISSN: 1989-6131 


\section{a. Design}

Once the participants' general data were collected, they had to watch a short video extract with no sound, included as a link at the end of the questionnaire ${ }^{1}$. The task, a narrative elicitation, consisted on recounting the video using their L1. They were given the opportunity of watching the video for a second time, if they deemed it neccessary. The video had no sound in either of the two languages so as not to influence the participants' production and induce transfer processes. The bilingual group production was recorded, transcribed by two independent researchers, and compared to that resulting from the same task as performed by the control group. Narratives have been previously used to elicit bilinguals' and learners' production and L1 attrition (see, for a revision, Pavlenko, 2003), presenting a number of advantages. First, using a soundless video extract elicits language which is less heterogeneous than spontaneous narratives, so the semantic referents are held constant. Second, it provides a specific context and background which may help participants as compared to other elicitation tasks. Third, video use is less artificial and more spontaneous than pictures. Fourth, with this type of task the external linguistic context does not affect the sample (Cook, 2003).

"To demonstrate the $\mathrm{L} 2 \rightarrow \mathrm{L} 1$ influence, we need to look for signs in the 1 production that reveal conceptual change. These signs must primarily be sought in the L1 vocabulary use and sentence building" (Cook, 2003:251). Clinical elicitation data which prompt elicited but unguided language use such as those obtained by the task presented in this study recalling a video extract constitute a type of data that "has unique strengths and weaknesses, and no single type of data will necessarily provide the best evidence for transfer" (Jarvis \& Pavlenko, 2008:34). In this sense, this was an etnographic and exploratory study which scrutinized a non guided sample of the L1 production of two groups of university students with differing L2 competence, use, and learning experence, in order to examine whether reverse transfer affects the native language of advanced learners in the tertiary context.

\section{RESULTS AND DISCUSSION}

The production of the two groups was recorded and transcribed by two independent researchers, reaching an agreement on the participants' corpus. An initial exploratory analysis was carried out, following the categorization adapted from Jarvis \& Pavlenko (2008) shown in Figure 1. We explored reverse transfer of verbal productions through an auditory channel and with a negative outcome. Two main areas of language were examined, lexis and syntax, as most studies up to date consider these two categories (Burton, 2013; Jarvis \& Pavlenko, 2008) and how they may be affected by cross-linguistic influence (see Figure 2). 


\begin{tabular}{|cccc|}
\hline Lexis & Syntax \\
\hline$\square$ & Mean length (words) & $\square$ & Mean length (sentences) \\
$\square$ & Language switch & $\square$ & Word order \\
$\square$ & False friends/cognates & $\square$ & Elliptical subjects \\
$\square$ & Calques (word) & $\square$ & Calques (prase) \\
\hline & & &
\end{tabular}

Figure 2. Taxonomy of measures analyzed in L1 corpus.

First, the number of total words and sentences per narrative was determined (Pavlenko, 2003). Then, the first category, lexis, explored L2 code switch (Bullock \& Toribio, 2009), use of false friends or cognates, and calques $^{2}$, both from the target language (Burton, 2013; Muñoz-Basol \& Salazar, 2016). The second category, syntax, examined whether there were examples of L2 word order (as in adjective+noun, rather than noun+adjective from the L1, Spanish) (Morett \& MacWhinney, 2013), use of elliptical/covert subjects, frequent in the L1 but not in the L2 (Balcom, 2003; Villa-García \& Suárez-Palma, 2016), and finally, phrase calques, involving a direct translation from a phrase or sentence from the L2 (Riera \& Romero, 2010). Results are shown in Table 7, below.

Table 7. Results for bilingual and control group. Italics are used for actual samples taken from corpus.

\begin{tabular}{|l|l|l|l|}
\hline \multicolumn{1}{|l|}{} & Bilingual group & Control group \\
\hline \multirow{5}{*}{ Lexis } & Mean length & 176.5 & 216 \\
\cline { 2 - 5 } & Language switch & - & OK \\
\cline { 2 - 5 } & False friends//cognates & - & - \\
\cline { 2 - 5 } & Calques & - & $\begin{array}{l}\text { Carro (coche-car) } \\
\text { Piso (suelo-ground) } \\
\text { Número previo } \\
\text { (número anterior- } \\
\text { previous number) }\end{array}$ \\
\hline \multirow{5}{*}{ Syntax } & Mean length (sentences) & 6.8 & 14 \\
\cline { 2 - 5 } & E.Subj (covert sj) & 6.5 & $\begin{array}{l}\text { Larga cola (cola } \\
\text { larga-long queue) }\end{array}$ \\
\cline { 2 - 5 } & W.order & $\begin{array}{l}\text { Va a ser atendido (5) } \\
\text { (atenderlo-be } \\
\text { attended/assisted) } \\
\text { Queda impedido (no } \\
\text { puede-is prevented) }\end{array}$ & $\begin{array}{l}\text { Esperar por su turno } \\
\text { (esperar su turno-wait } \\
\text { for his turn) } \\
\text { La cola está muy } \\
\text { larga (la cola es muy }\end{array}$ \\
\cline { 2 - 5 } & Calques (syntactic) & &
\end{tabular}

(C) Servicio de Publicaciones. Universidad de Murcia. All rights reserved. IJES, vol. 20(3), 2020, pp. 57-76 Print ISSN: 1578-7044; Online ISSN: 1989-6131 


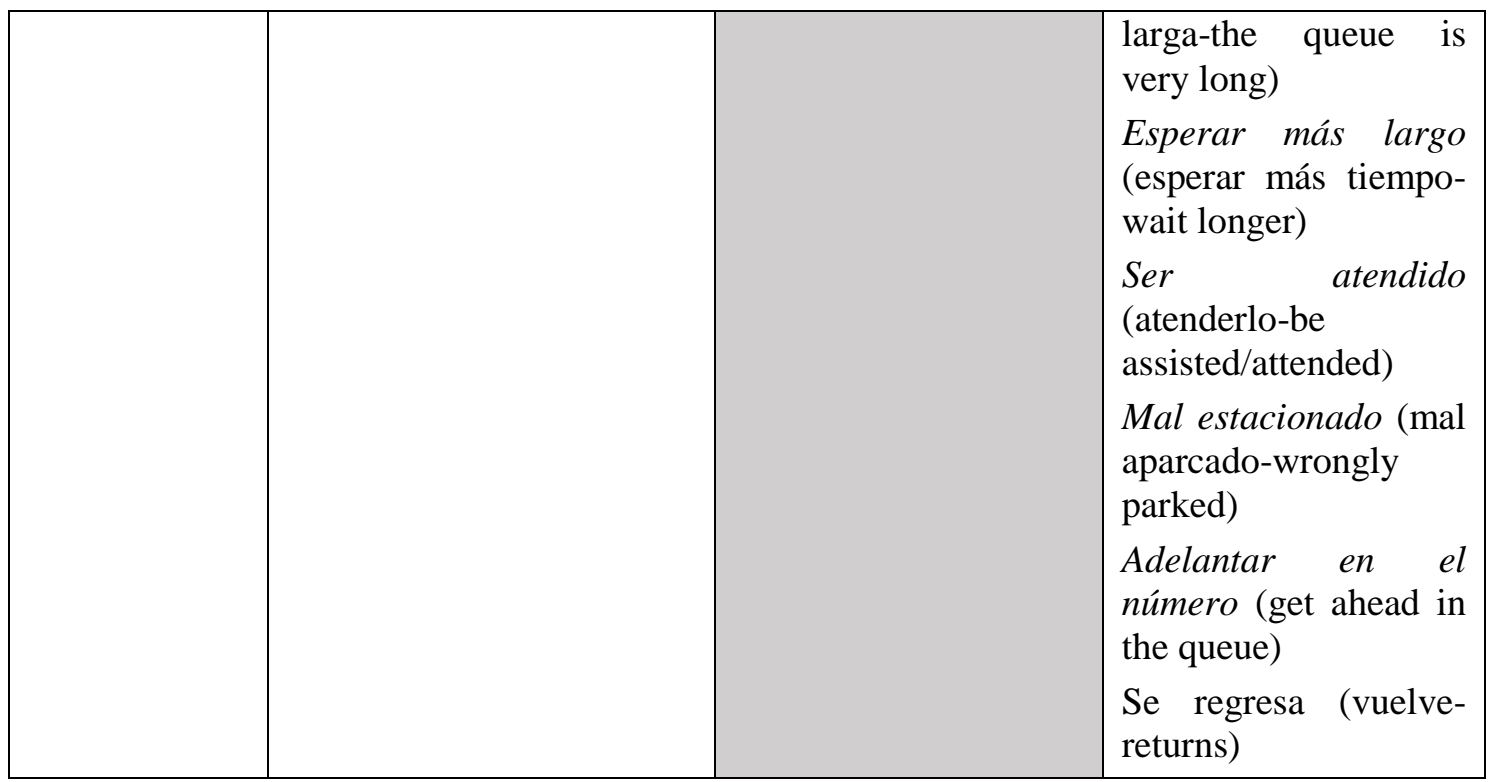

Although this was an exploratory study, some tentative conclusions can be drawn, which seem to be supported by other research but should later confirmed by further studies (Burton, 2013; Jarvis \& Pavlenko, 2008). Regarding lexis, participants in the bilingual group produced less words in their narratives, maybe because the L2 (English) is a more synthetic language, and this conciseness may have transferred to the L1 productions. Another explanation would entail that the subjects in this group were more skilled at summarizing in general or, alternatively, they might not have wanted to take too long in the task. There was just one instance of language switch, used as a communication strategy (filler) in the control group. Additionally, no obvious false friends were produced in either of the two groups, and although most participants used monitor and ticket in their narratives, nowadays they form part of the Spanish lexicon. Finally, some calques were used by the control group (see Table 7). This might be a manifestation of cultural, economic and political factors (Muñoz-Basol \& Salazar, 2016), or an evidence of the ever-widening influence of L2 input through videos received by learners/speakers of this generation. Thus, cross linguistic influence in the form of reverse transfer of lexical patterns was very weak for both groups, at least in those instances resulting in a negative outcome.

Considering syntax, the number of sentences produced by the bilingual group was significantly lower than that of the control group, in parallel to the individual word production discussed in the previous paragraph. Again, this might be due to L2 reverse transfer effects, to a higher skill at summarizing, or, in combination with this second explanation, to a need to finish the task as soon as possible. Elliptical or covert subjects were used with more frequency in the bilingual group, which seems to suggest lower transfer effects, as the subject in Spanish is an optional constituent whereas it is obligatory in English. Regarding word order (WO), there was only one instance of L2 WO in the control group L1 production (larga cola instead of cola larga), as adjectives and nouns follow an inverse order 
in each of the two languages ( $\mathrm{L} 1 \mathrm{~N}+\mathrm{Adj}, \mathrm{L} 2 \operatorname{adj}+\mathrm{N})$. Regarding the last category, phrase calques, they were relatively frequent in the control group (see Table 7), suggesting higher cross linguistic influence. Alternatively, it could be argued that the corpus of advanced learners (bilingual group) showed less reverse transfer effects, confirming results reported by other studies (Bouvy, 2000; Dewaele, 2001; Naves, Miralpeix \& Celaya, 2005; Williams \& Hammarberg 1998, in Burton, 2013). In sum, our study suggests there may be less unintentional L2 transfer to L1 in advanced learners. Alternatively, the type of transfer that took place in the production of multilingual speakers (bilingual group) had a positive outcome whereas that of less advanced learners (control group) may have had a negative outcome and thus be more evident. As Jarvis and Pavlenko argue (2008:51)

In cases such as these where one of the types of evidence for CLI is weak, the argument for transfer can still be made as long as the researcher is able to explain and justify with sufficient clarity why that type of evidence is weak and how CLI effects can still be demonstrated in the data.

Thus, it seems data from this exploratory study confirms results found in the literature, which suggest that a higher level in the L2 would involve lower (or less evident) negative transfer effects from that language to the L1 (Bouvy, 2000; Burton, 2013; Dewaele, 2001; Jarvis \& Pavlenko, 2008; Naves, Miralpeix \& Celaya, 2005; Williams \& Hammarberg 1998).

\section{CONCLUSIONS AND PEDAGOGICAL IMPLICATIONS}

Although the scope of the study did not allow scrutinizing unintentional reverse transfer beyond general lexical and syntactic measures, exploratory data seems to suggest there is more unintentional cross linguistic influence with a negative outcome in less advanced learners when the two languages being learnt/used are in contact. Alternatively, the language of more advanced learners may still be affected by a similar amount of transfer, but with a positive outcome, and this cross linguistic influence tends to be more problematical to identify (Jarvis \& Pavlenko, 2008).

Pedagogically speaking, if our comprehension of unintentional reverse transfer is maximized, establishing its positive results when there is an increased level of competence in the target language, we would be able to identify those language users who are effective at incorporating both languages in their linguistic uses. This holds very important implications for educational contexts where two languages are in contact, as the case of bilingual (CLIL) or EMI settings. Understanding how advanced or good learners are able to incorporate both languages would facilitate the learning of additional languages and further develop diverse teaching methodologies that combine two or more languages (CLIL, EMI). (C) Servicio de Publicaciones. Universidad de Murcia. All rights reserved. IJES, vol. 20(3), 2020, pp. 57-76 
Related to this, it might also enhance TEFL (Teaching English as a Foreign Language) training practices for future language teachers. In sum, current methodologies should incorporate the languages of multicompetent speakers/learners in their practice, as both languages are present in the user's mind, they complement each other, and they may improve the speakers' metalinguistic and cognitive skills (Bialystok et al., 2012; Flores \& Aneja, 2017).

However, to further support this exploratory study, the sample size should be increased, and a more systematic analysis of the sample ought to be implemented, examining aspects regarding lexical diversity and syntactic patterns by means of corpus linguistics or other alternative procedures (see, for example, the revisions of Alonso, 2016; Treffers-Daller \& Sakel, 2012). Additionally, further tasks combining L1 and L2 use should be incorporated. Confirming the words of Burton (2013:12) "this is of course speculation and further research would be needed to confirm such a hypothesis".

\section{ENDNOTES}

1. Retrieved 4 march, 2018 from https://www.youtube.com/watch? $=2 \mathrm{v} 3 \mathrm{mLxd} 2 \mathrm{FfA}$

2. Words with a similar form in both languages but used in one language with the meaning they have in the other language. Calques, on the other hand, are words borrowed from the other language. They may suffer some changes to approximate them to the L1, for example adding a suffix.

\section{REFERENCES}

Alonso, R. (Ed.) (2016). Crosslinguistic Influence in Second Language Acquisition. Bristol: Multilingual Matters. doi:10.21832/9781783094837

Alonso, R., Cadierno, T. \& Jarvis, S. (2016). Crosslinguistic influence in the acquisition of spatial prepositions in English as a foreign language. In R. Alonso (Ed.), Crosslinguistic Influence in Second Language Acquisition (pp. 93-120). Bristol: Multilingual Matters. doi:10.21832/9781783094837

Athanasopoulos, P. \& Boutonnet, B. (2016). Learning grammatical gender in a second language changes categorization of inanimate objects: Replications and new evidence from English learners of L2 French. In R. Alonso (Ed.), Crosslinguistic Influence in Second Language Acquisition (pp. 173-192). Bristol: Multilingual Matters. doi:10.21832/9781783094837-011 
Aronin, L. \& Hufeisen, B. (Eds.) (2009). The Exploration of Multilingualism: Development of Research on L3, Multilingualism and Multiple Language Acquisition (Vol. 6). John Benjamins Publishing.doi:10.1075/aals.6

Bialystok, E., Craik, F. I. \& Luk, G. (2012). Bilingualism: consequences for mind and brain.

Trends in Cognitive Sciences, 16 (4), 240-250.doi:10.1016/j.tics.2012.03.001

Bates, E. \& MacWhinney, B. (1989). Functionalism and the Competition Model. In B. MacWhinney \& E. Bates (Eds.), The Crosslinguistic Study of Sentence Processing (pp. 3-73). Cambridge, UK: Cambridge University Press.

Bouvy, C. (2000). Towards the construction of a theory of cross-linguistic transfer. In J. Cenoz \& U. Jessner (Eds.), English in Europe: The Acquisition of a Third Language (pp.143-156). Clevedon: Multilingual Matters.

Bullock, B.E. \& Toribio, A.J. (2009). Themes in the study of code-switching. In B. E. Bullock \& A. J. Toribio (Eds.), The Cambridge Handbook of Linguistic Code-switching (pp. 1-18). Cambridge: Cambridge University Press. doi:10.1017/CBO9780511576331.002

Burton, G. (2013). Cross-linguistic influence in non-native languages: explaining lexical transfer using language production models. International Journal of Multilingualism, 10(1), 4659.doi:10.1080/14790718.2012.679274

Cenoz, J. (2003). The additive effect of bilingualism on third language acquisition: A review. International Journal of Bilingualism, 7(1), 71-87. doi:10.1177/13670069030070010501

Chamorro, G., Sorace, A. \& Sturt, P. (2016). What is the source of L1 attrition? The effect of recent L1 re-exposure on Spanish speakers under L1 attrition. Bilingualism: Language and Cognition, 19(3), 520-532.doi:10.1017/S1366728915000152

Cook, V. (2003). Introduction: The Changing L1 in the L2 User's Mind. In V. Cook (Ed.), Effects of the Second Language on the First (pp. 1-18). Clevedon: Multilingual Matters. doi:10.21832/9781853596346-003

Cook, V. (2009). Multilingual Universal Grammar as the norm. In Y. Leung (Ed.), Third Language Acquisition and Universal Grammar (pp. 55-70). Clevedon: Multilingual Matters.doi:10.21832/9781847691323-006

Council of Europe. (2001). Common European Framework of Reference for Languages. Learning, Teaching, Assessment. Cambridge: Cambridge University Press.

Council of Europe. (2018). Common European Framework of Reference for Languages: Learning, Teaching and Assessment (CEFR). Companion Volume with New Descriptors. Retrieved 10 September, 2018 from https://rm.coe.int/cefr-companion-volume-with-new-descriptors2018/1680787989

Cuza, A. (2013). Crosslinguistic influence at the syntax proper: Interrogative subject-verb inversion in heritage Spanish. International Journal of Bilingualism, 17(1), 71-96. doi: $10.1177 / 1367006911432619$

De Angelis, G. \& Dewaele, J. M. (Eds.) (2011). New Trends in Crosslinguistic Influence and Multilingualism Research. Bristol: Multilingual Matters.doi:10.21832/9781847694430

Dearden, J. (2015). English Medium Instruction: A Growing Global Phenomenon. British Council Report. Retrieved 25 November from http://goo.gl/2Gh1Zd 
Dewaele, J. (2001). Activation or inhibition? The interaction of L1, L2 and L3 on the language AQ15 mode continuum. In J. Cenoz, B. Hufeisen \& U. Jessner (Eds.), Cross-linguistic Influence in Third Language Acquisition: Psycholinguistic perspectives (pp. 69-89). Clevedon: Multilingual Matters. doi:10.21832/9781853595509-006

Duguine, I. \& Köpke, B. (2019). Processing strategies used by Basque-French bilingual and Basque monolingual children for the production of the subject-agent in Basque. Linguistic Approaches to Bilingualism, 9(4-5). doi:10.1075/lab.16047.dug

Ekiert, M., Han, Z. \& Alonso, R. (2016). L1-fraught difficulty: The case of L2 acquisition of English articles by Slavic speakers. In R. Alonso (Ed.), Crosslinguistic Influence in Second Language Acquisition (pp. 95-147). Bristol: Multilingual Matters. doi:10.21832/9781783094837-010

Flores, N. \& Aneja, G. (2017). "Why Needs Hiding?" Translingual (Re)Orientations in TESOL Teacher Education. Research in the Teaching of English, 51(4), 441-463.

Helms-Park, R. \& Dronjic, V. (2016). Cross-linguistic lexical influence: Cognate facilitation. In R. Alonso (Ed.), Crosslinguistic Influence in Second Language Acquisition (pp. 71-92). Bristol: Multilingual Matters.doi:10.21832/9781783094837-007

Hinkel, E. (Ed.) (2011). Handbook of Research in Second Language Teaching and Learning. Vol II. London: Routledge. doi:10.4324/9780203836507

Jarvis, S. \& Pavlenko, A. (2008). Crosslinguistic Influence in Language and Cognition. London: Routledge.doi:10.4324/9780203935927

Jessner, U., Megens, M. \& Graus, S. (2016). Crosslinguistic influence in third language acquisition. In R. Alonso (Ed.), Crosslinguistic Influence in Second Language Acquisition (pp. 192-214). Bristol: Multilingual Matters. https://doi.org/10.21832/9781783094837-012

Kellerman, E. (1986). An eye for an eye: Crosslinguistic constraints on the development of the L2 lexicon. In E. Kellerman \& M. Sharwood Smith (Eds.), Crosslinguistic Influence in Second Language Acquisition (pp. 35-48). New York: Pergamon.

Larsen-Freeman, D. \& Long, L. (2014). An Introduction to Second Language Acquisition Research. Abingdon: Routledge. doi:10.4324/9781315835891

Lasagabaster, D. \& Doiz, A. (Eds.) (2016). CLIL Experiences in Secondary and Tertiary Education. Peter Lang AG, Internationaler Verlag der Wissenschaften. doi:10.3726/978-3-0351-0929-0

Mehisto, P. \& Genesee, F. (2015). Building Bilingual Education Systems. Cambridge: Cambridge University Press.

Moattarian, A. (2013). Bidirectional crosslinguistic influence in language learning: Linguistic aspects and beyond. International Journal of Linguistics, 5(4), 38. doi:10.5296/ijl.v5i4.3746

Morett, L. M. \& MacWhinney, B. (2013). Syntactic transfer in English-speaking Spanish learners. Bilingualism: Language and Cognition, 16(1), 132-151. doi:10.1017/S1366728912000107

Muñoz-Basols, J. \& Salazar, D. (2016). Cross-linguistic lexical influence between English and Spanish. Spanish in Context, 13(1), 80-102. doi:10.1075/sic.13.1.04mun

Navés, T., Miralpeix, I. \& Luz Celaya, M. (2005). Who transfers more... and what? Crosslinguistic influence in relation to school grade and language dominance in EFL. International Journal of Multilingualism, 2(2), 113-134. doi:10.1080/14790710508668380

Norris, J. \& Ortega, L. (2012). Assessing learner knowledge. In S. Gass \& A. MacKey (Eds.), The Routledge Handbook of Second Language Acquisition (pp. 573-590). London: Routledge.

(C) Servicio de Publicaciones. Universidad de Murcia. All rights reserved. IJES, vol. 20(3), 2020, pp. 57-76 Print ISSN: 1578-7044; Online ISSN: 1989-6131 
Odlin, T. (2006). Could a contrastive analysis ever be complete? In J. Arabski (Ed.), Cross-linguistic Influence in the Second Language Lexicon (pp. 22-35). Clevedon: Multilingual Matters. doi:10.21832/9781853598579-006

Ortega, L. (2008). Understanding Second Language Acquisition. London: Routledge.

Pavlenko, A. (2003). I Feel Clumsy Speaking Russian': Influence on L7 in Narratives of Russian 12 Users of English. In V. Cook (Ed.), Effects of the Second Language on the First (pp. 31-62). Clevedon: Multilingual Matters.

Pavlenko, A. (2016). Whorf's Lost Argument: Multilingual Awareness. Language Learning, 66 (3), 581-607. doi:10.1111/lang.12185

Riera, J. B. \& Romero, E. D. (2010). Structural calques: source language interference in CLIL lectures in Spain. Current Research on CLIL 3, 5.

Selinker, L. (1972). Interlanguage. IRAL-International Review of Applied Linguistics in Language Teaching 10 (1-4), 209-232. doi:10.1515/iral.1972.10.1-4.209

Selinker, L. \& Rutherford, W. (2013). Rediscovering Interlanguage. Abingdon, England: Routledge.doi:10.4324/9781315845685

Stockwell, R.P., Bowen, J.D. \& Martin, J.W. (1965). The Grammatical Structures of English and Spanish. Chicago: University of Chicago Press.

Tarone, E. (2006). The Interlanguage Hypothesis. Science Direct, 4, 747-752. doi:10.1016/B0-08044854-2/00618-0

Tarone, E. (2018). Interlanguage. In. C.A. Chapelle (Ed.), The Encyclopedia of Applied Linguistics (pp. 1-7). Wiley Online Library. doi:10.1002/9781405198431.wbeal0561.pub2

Treffers-Daller, J., \& Sakel, J. (2012). Why transfer is a key aspect of language use and processing in bilinguals and L2-users. International Journal of Bilingualism, 16(1), 3-10. doi:10.1177/1367006911403206

Turnbull, M. \& Dailey-O'Cain, J. (2009). Concluding reflections: Moving forward. In M. Turnbull \& J. Dailey-O'Cain (Eds.), First Language Use in Second and Foreign Language Learning (pp. 182-186). Bristol: Multilingual Matters. doi:10.21832/9781847691972-013

Vasilyeva, M., Waterfall, H., Gámez, P. B., Gómez, L. E., Bowers, E. \& Shimpi, P. (2010). Crosslinguistic syntactic priming in bilingual children. Journal of Child Language, 37(5), 10471064. doi:10.1017/S0305000909990213

Villa-García, J. \& Suárez-Palma, I. (2016). Early null and overt subjects in the Spanish of simultaneous English-Spanish bilinguals and Crosslinguistic Influence. Revista Española de Lingüística Aplicada/Spanish Journal of Applied Linguistics, 29(2), 350-395. doi:10.1075/resla.29.2.01vil

Weinreich, U. (1953). Languages in Contact. The Hague: Mouton.

Williams, S. \& Hammarberg, B. (1998). Language switches in L3 production: Implications for a polyglot speaking model. Applied linguistics, 19(3), 295-333. doi:10.1093/applin/19.3.295

Woll, N. (2018). Investigating dimensions of metalinguistic awareness: what think-aloud protocols revealed about the cognitive processes involved in positive transfer from L2 to L3. Language Awareness, 27(1-2), 167-185. doi:10.1080/09658416.2018.1432057

(C) Servicio de Publicaciones. Universidad de Murcia. All rights reserved. IJES, vol. 20(3), 2020, pp. 57-76 Print ISSN: 1578-7044; Online ISSN: 1989-6131 


\section{APPENDIX}

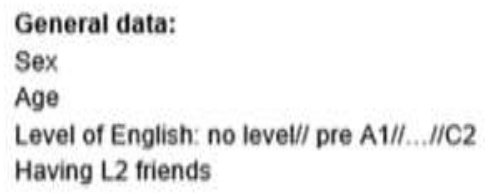

\begin{tabular}{|c|c|c|c|c|c|c|}
\hline Starting age for $L 2$ learning & $\begin{array}{l}5 \text { years of } \\
\text { less }\end{array}$ & $5-8$ years & 8-12 years & $\begin{array}{l}12-16 \\
\text { years }\end{array}$ & \multicolumn{2}{|c|}{16 onwards } \\
\hline $\begin{array}{l}\text { Number of years learning the } \\
\mathrm{L}_{2}\end{array}$ & $\begin{array}{l}\text { Less than } 2 \\
\text { years }\end{array}$ & 2.4 years & 4.6 years & $6-8$ years & \multicolumn{2}{|c|}{$\begin{array}{l}\text { More than } 8 \\
\text { years }\end{array}$} \\
\hline Type of learning context & $\begin{array}{l}\text { Mainstream } \\
\text { education } \\
\text { (ME) }\end{array}$ & $\begin{array}{l}\text { L2 } \\
\text { country } \\
\text { no formal } \\
\text { support } \\
\text { (FS) }\end{array}$ & $\begin{array}{l}\text { ME \& L2 } \\
\text { country }\end{array}$ & $\begin{array}{l}\text { ME \& } \\
\text { Private } \\
\text { academy }\end{array}$ & $\begin{array}{l}\text { Privat } \\
\text { e } \\
\text { acade } \\
\text { my }\end{array}$ & \begin{tabular}{|l} 
L1 \\
countr \\
y no \\
FS
\end{tabular} \\
\hline \multirow[t]{4}{*}{ Inmersion periods in L2 country } & \multicolumn{6}{|c|}{ length } \\
\hline & $\begin{array}{l}1 \text { month of } \\
\text { less }\end{array}$ & $\begin{array}{l}1.3 \\
\text { months }\end{array}$ & $3-6$ months & $\begin{array}{l}6 \text { monts- } \\
1 \text { year }\end{array}$ & $\begin{array}{l}1.2 \\
\text { years }\end{array}$ & \begin{tabular}{|l|l} 
More \\
than 2 \\
years
\end{tabular} \\
\hline & \multicolumn{6}{|c|}{ type } \\
\hline & $\begin{array}{l}\text { English } \\
\text { family }\end{array}$ & $\begin{array}{l}\text { English } \\
\text { family } \\
\text { with L1 } \\
\text { students }\end{array}$ & \begin{tabular}{l|} 
English \\
family with \\
diverse L1 \\
students
\end{tabular} & $\begin{array}{l}\text { Flat } \\
\text { residenc } \\
\text { e with L2 } \\
\text { natives }\end{array}$ & \multicolumn{2}{|c|}{$\begin{array}{l}\text { Flat/ residence } \\
\text { with L1 natives }\end{array}$} \\
\hline \multirow[t]{2}{*}{ Inmersion periods in L1 country } & \multicolumn{6}{|c|}{ Length } \\
\hline & 1 week & \multicolumn{2}{|c|}{1 week-1 month } & $\begin{array}{l}1-6 \\
\text { months }\end{array}$ & \multicolumn{2}{|c|}{$\begin{array}{l}6 \text { months of } \\
\text { more }\end{array}$} \\
\hline
\end{tabular}

\section{L2 Use:}

\begin{tabular}{|c|c|c|c|c|c|c|}
\hline Context & Nowhere & Home & $\begin{array}{l}\text { (some) } \\
\text { friends }\end{array}$ & University & $\begin{array}{l}\text { Internet/computer } \\
\text { related activities }\end{array}$ & $\begin{array}{l}\text { Two or } \\
\text { more } \\
\text { options }\end{array}$ \\
\hline \multirow{4}{*}{$\begin{array}{l}\text { Type of } \\
\text { receptive } \\
\text { skill used }\end{array}$} & \multicolumn{6}{|c|}{ reading } \\
\hline & \multicolumn{2}{|l|}{ In the L1 } & \multicolumn{2}{|c|}{ In the L2 } & \multicolumn{2}{|l|}{ L1 \& L2 } \\
\hline & \multicolumn{6}{|c|}{ listening } \\
\hline & \multicolumn{2}{|l|}{ In the L1 } & \multicolumn{2}{|c|}{ In the $\mathrm{L} 2$} & \multicolumn{2}{|l|}{ L1 \& L L } \\
\hline $\begin{array}{l}\text { Hours per } \\
\text { week using } \\
\text { L2 }\end{array}$ & 5 or less & $5-10$ & $10-15$ & $15-20$ & More than 20 & \\
\hline
\end{tabular}

Open question: describe your learning experience

Adapted from questionnaire sent to participants' emails to complete in Google docs, available at https://docs.google.com/forms/d/e/1FAIpQLSdTRIZ6TbfYqlJ9poH5ua18s9vzX1DO4rb5MSQVGJu8ZaRNQ/viewform?vc=0\&c=0\&w=1 